\section{Godt om kognitiv svikt}

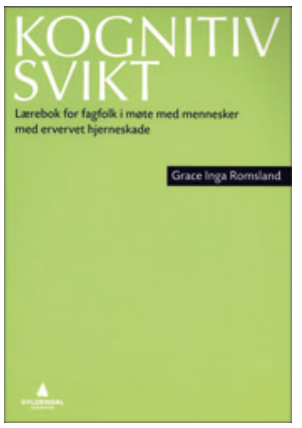

Grace Inga Romsland

Kognitiv svikt

Lærebok for fagfolk i møte med mennesker med ervervet hjerneskade.

196 s. Oslo: Gyldendal Akademisk, 2011.

Pris NOK 238

ISBN 978-82-05-41567-6

Grace Inga Romsland er fagsjef i sykepleie og forsker ved Sunnaas sykehus. Hun har erfaring fra både kommunehelsetjenesten og spesialisthelsetjenesten. Bakgrunn for boken er hennes doktorgradsarbeid i medisinsk antropologi. Målgruppen er studenter på masterog videreutdanningsnivå innenfor rehabilitering, slagbehandling, eldreomsorg, sykepleie og andre helsefag, men også leger og andre yrkesutøvere som møter pasienter med ervervet hjerneskade. Intensjonen er å gi kunnskap om hjerneskader og å bidra til at behandlere kan sette tilværelsen med kognitiv svikt $i$ et større perspektiv. Boken skal også vise betydningen av tilrettelegging, omsorg og rehabilitering ved tilstander med kognitiv svikt. Den gir innsikt i strategier mange med kognitiv svikt benytter for å mestre sin hverdag.

Innledningsvis beskriver forfatteren bakgrunn, søkelys og målgruppe. Første kapittel om kognitiv svikt og hjernens rolle er kortfattet, men danner et bakgrunnsteppe for de videre temaene. Forfatteren starter hvert kapittel med en kort gjennomgang av temaet i kapitlet. Ved å bruke pasienthistorier eksemplifiserer og forklarer hun de ulike teoriene. Pasienthistoriene er svært illustrerende, vever teori og praksis sammen på en god måte og er troverdige. Språket er lettfattelig og flyter bra.

Vi får innblikk i hvordan det er å leve med en hjerneskade og hvilke faser en skadet person kan gå gjennom. Forfatteren illustrerer også ulike former for kognitiv svikt og hvordan disse kan oppleves både av pasient og helsepersonell. Man får godt innblikk i det sammenbruddet det er å bli skadet, og utfordringen med å finne ny forankring i tilværelsen. Viktige temaer som likeverd, stigmatisering, normer og forventninger beskrives bra. Teorier innen fagfelt som sosiologi, sosialantropologi og kulturhistorie, benyttes for å forklare pasientenes reaksjoner og møte med omverdenen. Ved hjelp av pasienthistoriene unngår fremstillingen å bli for teoretisk. Spesielt bra er beskrivelsen av forholdet til andre, der forfatteren tar for seg Goffmanns teori om selvpresentasjon og ulike beskyttende praksiser. Den skadedes forhold til det moderne samfunnet med krav til «multitasking», kulturens betydning og livsplanlegging drøftes godt. Til slutt stakes veien videre i livet, og forfatteren evner kritisk å vurdere rehabilitering av hjerneskadede og dilemmaer i tilknytning til dette.

Som lege er mange av de teoriene og deres opphav som beskrives, ukjent, men interessant lesning. Mange av uttrykkene som benyttes, for eksempel ontologisk og salutogen, er fremmede, og på tross av at de blir forklart, hadde en kort ordliste vært til god nytte.

Romsland har lykkes med å lage en bok som gir god innsikt i utfordringene ved å pådra seg og leve med ervervet hjerneskade. Hun evner å sette dette i et samfunnsmessig og kulturelt perspektiv. Boken åpner for refleksjon om hvordan vi som helsearbeidere, men også samfunn møter pasienter med funksjonssvikt. Jeg anbefaler boken spesielt til kolleger som arbeider med eller har interesse for ervervede hjerneskader.

\section{Torgeir Hellstrøm}

Avdeling for fysikalsk medisin og rehabilitering

Oslo universitetssykehus

\section{Marta Steinsviks fascinerende liv}

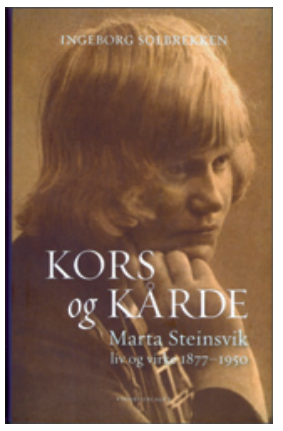

Ingeborg Solbrekken
Kors og kårde

Marta Steinsviks liv og virke 1877-1950. 656 s, ill. Oslo: Vidarforlaget, 2012. Pris NOK 399 ISBN 978-82-7990-108-2

Jeg har lenge ment at det burde skrives en moderne biografi om den betydelige landsmålsforkjemperen og bladfyken Rasmus Steinsvik (1863-1913). I stedet har Ingeborg Solbrekken latt seg inspirere av hans kone Marta (1877-1950), og det er ikke vanskelig å forstå. Marta Steinsvik var en usedvanlig fargerik personlighet. Til tross for at hun aldri hadde noen formell posisjon som ståsted for sitt engasjement, gjorde hun seg i høy grad bemerket i sin samtid først og fremst som en hvass og provoserende samfunnsdebattant og en glimrende foredragsholder. Hun bidro til utviklingen av landsmålet med artikler i avisen Den 17de Mai og som oversetter av utenlandsk litteratur. I tillegg kom hun tidlig med i de fremvoksende teosofiske og antroposofiske miljøene her i landet på begynnelsen av 1900-tallet. Hun ble kjent med Rudolf Steiner (1861-1925), som hun forelsket seg voldsomt i, men han avviste henne. Hennes rike intellektuelle evner i kombinasjon med et energisk vitebegjær, gjorde henne til en kunnskapsrik kvinne. Det ble lagt vekt på hennes argumenter da presteembetet ble åpnet for kvinner i 1938. Dessverre ble hun også lyttet til da hun i mellomkrigstiden holdt en rekke antisemittiske foredrag. Men mest kjempet hun i motvind, også i sin siste brave kamp etter krigen, da hun påviste en rekke eksempler på mishandling av landssvikdømte fanger.

Ingeborg Solbrekken har hatt tilgang til Marta Steinsviks etterlatte papirer, en unik kilde til opplysninger om hennes turbulente liv. Solbrekken får godt frem hvilken kampnatur hun var, og at det ikke bare skyldtes hennes «natur», men også det traumet hun ble påført i forbindelse med at hun i 1910, 33 år gammel, ble erklært sinnssyk og tvangsinnlagt på Gaustad asyl av Johan Scharffenberg (1869-1965). Selv mente hun at hun aldri hadde vært psykisk syk, og får støtte av sin biograf på noe tynt grunnlag. Hulda Garborg (1862-1934), som sto Marta Steinsvik nær i denne vanskelige tiden, var ikke i tvil om hennes galskap, men Solbrekken har ikke lest Hulda Garborgs dagbøker.

Legestanden hadde ingen høy stjerne hos Marta Steinsvik, og i særdeleshet ikke psykiaterne. Solbrekken er på parti med Steinsvik $\mathrm{i}$ hennes kamp mot legevitenskapens forsøk med dyr og likeledes når Karl Evangs (1902-81) angivelige blinde tro på vaksinasjonsprogrammer får det glatte lag. Steinsvik er heller ikke nådig mot professor Johan Gustav Edvin Bruusgaards (1869-1934) såkalte medisinske eksperimenter med barn fra lavere sosiale sjikt. Forfatteren legger seg tidvis tett på biografiobjektet, noe som kan bli litt ensidig, og det er ikke alltid godt å vite hvem av dem som taler. Litt for ofte er teksten innforstått og dermed uklar, og det er mange slurvefeil. Og hvorfor skrive hele 16 sider om Køber-saken, hvor Solbrekken lar Johan Scharffenberg og Ragnar Vogt (1870-1943) få gjennomgå, når det eneste Marta Steinsvik gjorde, var å sitte i retten som tilhører? Det er også synd at biografien ikke har personregister. Men selv om boken burde vært både strammet inn og bedre redigert, skal Solbrekken ha ros for å ha funnet frem til svært mye interessant stoff. Biografien om Marta Steinsvik er derfor ikke kjedelig lesning.

Per E. Hem

Oslo 